\title{
구리 $(\mathrm{Cu})$ 노출에 따른 전복, Haliotis discus hannai의 생체축적 및 성장의 변화
}

\author{
박희주 · 강주찬
}

부경대학교 수산생명의학과

\section{Bioaccumulation and growth change in the abalone Haliotis discus hannai exposed to copper}

\author{
Hee Ju Park and Ju Chan Kang ${ }^{\dagger}$ \\ Department of Aquatic Life Medicine, Pukyong National University, Busan 608-737, Korea
}

\begin{abstract}
The objective of this study was to investigate the effects of exposured $\mathrm{Cu}^{2+}$ on growth and bioaccumulation of abalone Haliotis discus hannai. Abalone were exposed to various concentration of $\mathrm{Cu}^{2+}(0,5,10,20,40 \mu \mathrm{g} / \mathrm{L})$. Bioaccumulation of tissues, hepatopancreas, muscles and gills were measured. hepatopancreas and gills $\mathrm{Cu}^{2+}$ concentration of abalone increases to extent during the 4 weeks accumulation time. But muscles showed no significant changes, with respect to control. These data indicate that abalone Haliotis discus hannai hepatopancreas and gills can be considered adequate target tissues for waterborne exposured of $\mathrm{Cu}^{2+}$. Weight growth rate of abalone exposed to $\mathrm{Cu}^{2+}$ was significantly decreased in 20 and $40 \mu \mathrm{g} / \mathrm{L}$ groups compared to control. This study revealed that high $\mathrm{Cu}^{2+}$ concentration $(\geq 20$ $\mu g / \ell)$ reduced growth of abalone. These data indicate that excessive waterborne $\mathrm{Cu}^{2+}$ can affect the toxicity of xenbiotics to abalone through alterations in growth rate. Thus, environmental standard of $\mathrm{Cu}^{2+} 20 \mu \mathrm{g} / \mathrm{L}$, should be considered a potential source of variation in toxicological studies with abalone.
\end{abstract}

Key words : $\mathrm{Cu}^{2+}$ toxicity, Abalone, Growth rate, Bioaccumulation

해양에 존재하는 각종 금속들은 직접 또는 여러 가지 변화를 거치면서 해양생물의 체내에 흡수되며 (Bryan, 1976), 체내로 흡수된 금속들은 항상성의 유 지, 각종 물질 대사 및 효소의 보조인자로 사용되기도 하지만(Geret and Bebianno, 2004), 고농도의 장기간 의 노출은 독성을 유발하게 된다(Wang and Fisher, 1999). 일반적으로 수중에 존재하는 구리이온 $\left(\mathrm{Cu}^{2+}\right)$

†Corresponding author: Ju Chan Kang

Tel: +82-51-629-5944, Fax: +82-51-629-5938

E-mail: jckang@pknu.ac.kr
은 노출 시간과 노출 농도에 비례하여 갑각류 및 어류 등의 사망, 성장 및 생화학적 변동에 영향을 미치며 (Marr et al., 1996; Wong et al., 1999; Mcgeer et al., 2000; Sherba et al., 2000; Flik et al., 2002; Minghetti et al., 2008), 다모류, 이매패류 및 복족류 등에서 높은 생물농축이 보고되기도 한다(Bryan, 1976). 또한 어 류 및 갑각류의 성장률을 저하시키며(Marr et al. 1996; Minghetti et al. 2008; Wong et al. 1999; Mcgeer et al. 2000; Sherba et al. 2000; Flik et al. 2002), 해조류 의 물질대사에 영향을 미쳐 성장을 억제하기도 한다 
(Fernandes and Henriques, 1991; Lidon and Henriques, 1991; Lidon et al., 1993; Ouzounidou, 1994).

지금까지 연구는 구리이온이 가지는 어류에 대한 높은 독성연구가 대부분이며(Perschbacher and Wurts, 1999), 무척추동물에 관한 독성 연구는 미비한 실정 이다.

따라서 본 연구는 해양 무척추동물에 미치는 구리 이온의 영향을 파악하기 위하여 저서동물인 전복을 대상으로 구리이온 노출에 따른 이들의 기관별 축적 및 성장의 변화를 검토하였다.

\section{재료 및 방법}

\section{실험동물}

본 실험에 사용한 전복, Haliotis discus hannai은 제주도 소재의 양식장으로부터 분양받아 PVC (52× $36 \times 30 \mathrm{~cm})$ 수조에서 10 일간 순치하였고, 시험에는 외관상 건강한 개체(각장 $50.44 \pm 3.0 \mathrm{~mm}$, 전중 $14.74 \pm$ $2.5 \mathrm{~g}$ )를 사용하였다.

\section{실험조건}

모든 실험은 항온실 $\left(20 \pm 1^{\circ} \mathrm{C}\right)$ 에서 실시하였으며, 실 험에 사용한 해수의 수질은 Table 1과 같다. 시험용액 은 구리표준용액(copper standard solution, $\mathrm{CuSO}_{4}$ ) $1,000 \mathrm{mg} / \mathrm{L}$ 을 이용하여 예비실험을 바탕으로 5,10 , 20 및 $40 \mu \mathrm{g} / \mathrm{L}$ 로 설정하였다. 실험은 환수식 방법에 의해 매일 새로운 용액으로 교환하였고, 먹이는 매일 미역, Undaria pinnatifida을 충분한 양으로 공급 하였 고, 실험은 4주 동안 실시하였다.

\section{구리 분석}

전복의 조직 중 간췌장, 아가미 및 근육에 대하여 wet digestion method (APHA, 1992)를 이용하여 분석하
Table 1. The chemical components of seawater used in the experiments

\begin{tabular}{lc}
\hline Item & Value \\
\hline Temperature $\left({ }^{\circ} \mathrm{C}\right)$ & $20.0 \pm 1.0$ \\
$\mathrm{pH}$ & $8.1 \pm 0.2$ \\
Salinity $(\%)$ & $33.5 \pm 0.3$ \\
Dissolved oxygen $(\mathrm{mg} / \mathrm{L})$ & $7.1 \pm 0.2$ \\
Chemical oxygen demand $(\mathrm{mg} / \mathrm{L})$ & $1.2 \pm 0.1$ \\
Ammonia $(\mu \mathrm{g} / \mathrm{L})$ & $9.5 \pm 0.7$ \\
Nitrite $(\mu \mathrm{g} / \mathrm{L})$ & $5.3 \pm 0.3$ \\
Nitrate $(\mu \mathrm{g} / \mathrm{L})$ & $14.4 \pm 1.0$ \\
$\mathrm{Cu}(\mu \mathrm{g} / \mathrm{L})$ & $0.2 \pm 0.14$ \\
\hline
\end{tabular}

였다. 채취한 시료는 동결건조기를 이용하여 하루 동안 말린 후 건중량이 일정하도록 하였다. 1차로 건조된 시료는 각각 $3 \mathrm{ml}$ 의 $\mathrm{HNO}_{3}$ (suprapur grade, Merck Germany)와 섞어 산에 용해하고, 2차로 $120^{\circ} \mathrm{C}$ 의 열을 가하여 하루 동안 재 건조시켰다. 질산에 녹은 뒤 다시 건조된 시료는 $2 \% \mathrm{HNO}_{3} 20 \mathrm{ml}$ 을 첨가하여 membrane filter (Advantec mfs, Ins. $0.2 \mu \mathrm{m}$ )를 이용하여 필터링하여 보관하였다. 구리의 측정은 유도결합 플 라즈마 질량분석기(ICP-MS, Elan-DRc, Perkin-elmer Ltd.)를 이용하여 측정하였으며, 구리의 회수율을 알 아보기 위한 CRMs (certified reference materials)로는 ERM-CE278 (European Commission)을 이용하였다. 조직 내 함량은 $\mu \mathrm{g} / \mathrm{g}$ dry wt로 표현하였다.

\section{성장률 측정}

실험 개체는 실험 개시 2주마다 버니어 캘리퍼스 (No. 500, Mitutuyo, Japan)로 각장을 측정하였고, 전중 은 전자저울(HF-3000GD, A\&D Company, Ltd., Japan) 로 측정하여 다음과 같은 공식으로 WGR (Weight gain ratio, \%) 및 DISL (Daily increment in shell length, $\mu \mathrm{m} / \mathrm{day})$ 을 계산하였다. 
WER $(\%)=\left[\left(\mathrm{W}_{\mathrm{m}}-\mathrm{W}_{\mathrm{i}}\right) / \mathrm{W}_{\mathrm{m}}\right] \times 100$

$\operatorname{DISL}(\mu \mathrm{m} /$ day $)=\left[\left(\mathrm{SL}_{\mathrm{m}}-\mathrm{SL}_{\mathrm{i}}\right) / \mathrm{d}\right] \times 1,000$

$\mathrm{W}_{\mathrm{i}}$ - Initial weight $(\mathrm{g})$

$\mathrm{W}_{\mathrm{m}}$ - Experimented weight $(\mathrm{g})$

$\mathrm{SL}_{\mathrm{i}}$ - Initial shell length $(\mathrm{mm})$

$\mathrm{SL}_{\mathrm{m}}$ - Experimented shell length (mm)

d - Duration of the experiment in days

\section{유의성 검정}

실험 결과의 통계 처리는 SPSS 통계프로그램(version 12.0k)을 이용하여 ANOVA test를 실시한 후, 사후 검정은 다중 비교로 Duncan test를 사용하여 각 처리구 사이에 유의성 $(\mathrm{P}<0.05)$ 을 조사하였다 $(Z a r, 1996)$.

\section{결 과}

생체 내의 구리이온 축적

여러 가지 구리이온농도에 노출시킨 전복의 간췌 장 내의 구리이온의 변화를 Fig. 1에 나타내었다. 간췌

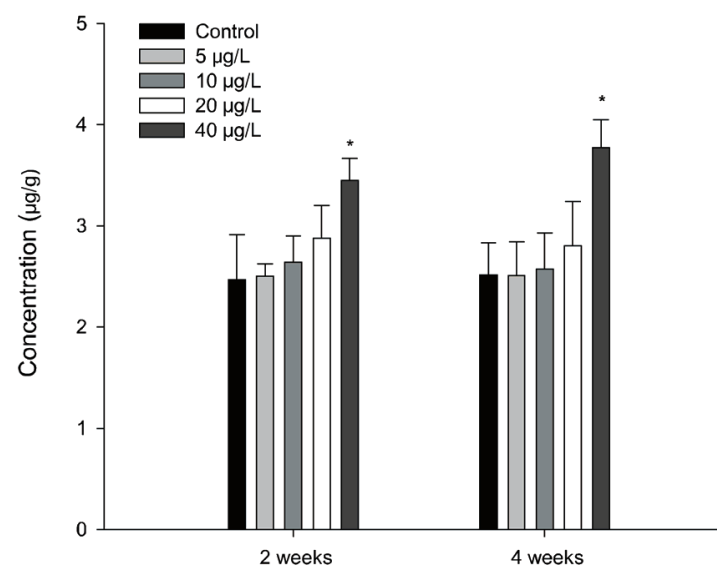

Fig. 1. Changes of $\mathrm{Cu}$ concentration in the hepatopancreas of the abalone Haliotis discus hannai exposed to various $\mathrm{Cu}$ concentrations for 4 weeks. Values are mean \pm S.E. $(n=7)$, *Values with superscript are significantly different $(\mathrm{P}<0.05)$ as determined by Duncan's test.
장 내의 구리이온은 노출한 구리이온의 농도가 높을 수록 증가하는 경향을 나타냈으나, 유의한 증가는 2 주 후의 $40 \mu \mathrm{g} / \mathrm{L}$ 농도에서 나타났다 $(\mathrm{P}<0.05)$. 여러 가지 구리이온의 노출에 따른 전복의 근육 내의 구리 이온의 변화를 Fig. 2에 나타내었다. 근육 내의 구리이 온은 $40 \mu \mathrm{g} / \mathrm{L}$ 노출농도에서 증가하는 경향을 나타냈 지만 모든 구리 노출농도에서 유의한 변화가 관찰되 지 않았다. 여러 가지 구리이온농도에 노출시킨 아가 미 내의 구리이온의 변화를 Fig. 3에 나타내었다. 아가 미 내의 구리이온농도는 $20 \mu \mathrm{g} / \mathrm{L}$ 이상의 노출농도에 서 2주후부터 유의한 증가가 관찰되었다 $(\mathrm{P}<0.05)$.

\section{성장률의 변화}

여러 가지 구리이온농도에 노출시킨 전복의 WER 변화를 Table 2에 나타내었다. WER은 구리이온농도 가 높을수록 감소하는 경향이 있으나, 유의한 감소 는 $40 \mu \mathrm{g} / \mathrm{L}$ 의 구리이온농도에서 4주후에 나타났다 $(\mathrm{P}<0.05)$. 여러 가지 구리이온농도에 노출시킨 전복 의 DISL (Daily increment in shell length)의 변화를

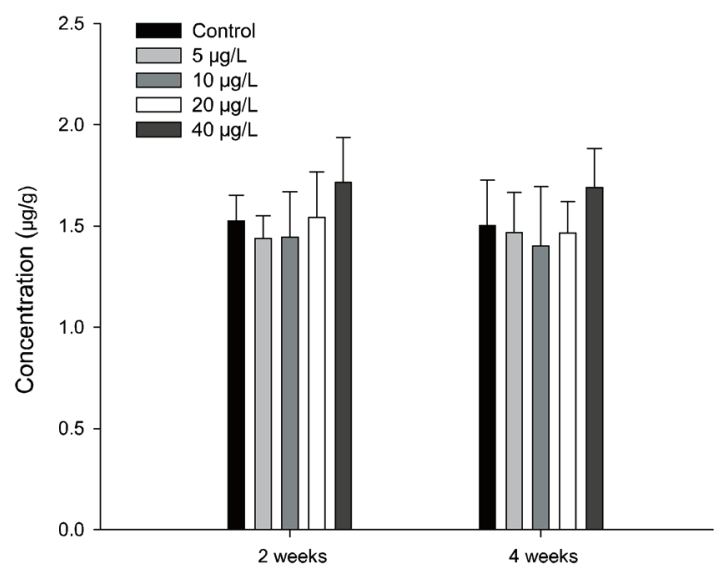

Fig. 2. Changes of $\mathrm{Cu}$ concentration in the muscle of the abalone Haliotis discus hannai exposed to various $\mathrm{Cu}$ concentrations for 4 weeks. Values are mean \pm S.E. ( $n=7$ ), *Values with superscript are significantly different $(\mathrm{P}<0.05)$ as determined by Duncan's test. 


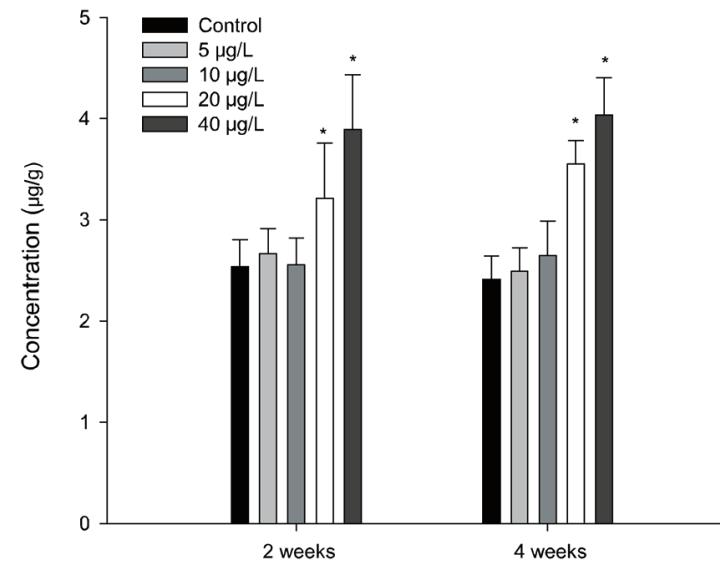

Fig. 3. Changes of $\mathrm{Cu}$ concentration in the gill of the abalone Haliotis discus hannai exposed to various $\mathrm{Cu}$ concentrations for 4 weeks. Values are mean \pm S.E. $(n=7)$, *Values with superscript are significantly different $(\mathrm{P}<0.05)$ as determined by Duncan's test.
Table 3에 나타내었다. DISL은 2주후, 구리이온농도 $40 \mu \mathrm{g} / \mathrm{L}$ 에서 유의한 감소가 보이며, 4주후의 경우 구리이온농도 $20 \mu \mathrm{g} / \mathrm{L}$ 이상에서 유의한 감소가 관찰 되었다 $(\mathrm{P}<0.05)$.

\section{고 찰}

해양척추동물의 중금속 축적은 노출기간과 노출 농도에 의해 영향을 받으며, 온도, 염분, 해수의 화학 적 특징, 생물의 연령이나 대사 등 여러 가지 요소에 의해 변동한다(Pagenkopf, 1983). 특정한 화학 물질에 대한 수생생물의 독성측정 과정에서 수온, $\mathrm{pH}$, 경도 및 용존산소량과 같은 조건외에도 유속 및 태양광선

Table 2. WGR (weight gain ratio) in abalone Haliotis discus hannai exposed to various $\mathrm{Cu}$ concentrations for 4 weeks

\begin{tabular}{|c|c|c|c|c|c|}
\hline \multirow{2}{*}{$\begin{array}{c}\text { Concentration } \\
(\mu \mathrm{g} / \mathrm{L})\end{array}$} & \multirow{2}{*}{$\begin{array}{c}\text { Initial weight } \\
\text { (g) }\end{array}$} & \multicolumn{2}{|c|}{ Weight (g) } & \multicolumn{2}{|c|}{ WGR (\%) } \\
\hline & & 2 weeks & 4 weeks & 2 weeks & 4 weeks \\
\hline Control & $14.71 \pm 0.23$ & $15.84 \pm 0.22$ & $16.53 \pm 0.33$ & $7.68 \pm 0.04$ & $11.49 \pm 0.12$ \\
\hline 5 & $14.80 \pm 0.13$ & $15.95 \pm 0.07$ & $16.62 \pm 0.32$ & $7.77 \pm 0.10$ & $11.41 \pm 0.12$ \\
\hline 10 & $15.05 \pm 0.26$ & $16.21 \pm 0.31$ & $16.89 \pm 0.13$ & $7.71 \pm 0.11$ & $11.35 \pm 0.25$ \\
\hline 20 & $14.26 \pm 0.11$ & $15.35 \pm 0.21$ & $16.04 \pm 0.16$ & $7.64 \pm 0.14$ & $11.30 \pm 0.18$ \\
\hline 40 & $14.84 \pm 0.09$ & $15.94 \pm 0.14$ & $16.50 \pm 0.18$ & $7.41 \pm 0.10$ & $10.41 \pm 0.20^{*}$ \\
\hline
\end{tabular}

Values are mean \pm S.E. $(\mathrm{n}=7)$, *Values with superscript are significantly different $(\mathrm{P}<0.05)$ as determined by Duncan's test.

Table 3. DISL (Daily increment in shell length) in abalone Haliotis discus hannai exposed to various $\mathrm{Cu}$ concentrations for 4 weeks

\begin{tabular}{|c|c|c|c|c|c|}
\hline \multirow{2}{*}{$\begin{array}{c}\text { Concentration } \\
(\mu \mathrm{g} / \mathrm{L})\end{array}$} & \multirow{2}{*}{$\begin{array}{l}\text { Initial length } \\
(\mathrm{mm})\end{array}$} & \multicolumn{2}{|c|}{ Length (mm) } & \multicolumn{2}{|c|}{ DISL $\left(\mu \mathrm{m} \mathrm{d}^{-1}\right)$} \\
\hline & & 2 weeks & 4 weeks & 2 weeks & 4 weeks \\
\hline Control & $50.03 \pm .077$ & $50.94 \pm 0.21$ & $51.50 \pm 0.44$ & $65.00 \pm 1.21$ & $52.50 \pm 1.11$ \\
\hline 5 & $50.17 \pm 0.81$ & $51.05 \pm 0.61$ & $51.66 \pm 0.51$ & $62.86 \pm 0.88$ & $53.21 \pm 1.31$ \\
\hline 10 & $51.33 \pm 0.48$ & $52.23 \pm 0.52$ & $52.76 \pm 0.36$ & $64.29 \pm 0.79$ & $51.07 \pm 0.79$ \\
\hline 20 & $50.22 \pm 0.49$ & $51.11 \pm 0.31$ & $51.54 \pm 0.41$ & $63.57 \pm 1.02$ & $47.14 \pm 0.92^{*}$ \\
\hline 40 & $50.10 \pm 0.79$ & $50.89 \pm 0.39$ & $51.41 \pm 0.71$ & $56.43 \pm 1.33^{*}$ & $46.79 \pm 0.81^{*}$ \\
\hline
\end{tabular}

Values are mean \pm S.E. $(\mathrm{n}=7)$, *Values with superscript are significantly different $(\mathrm{P}<0.05)$ as determined by Duncan's test. 
등의 물리적 요인과 성장시기 및 건강상태 등의 생태 적 요인에 의해서 상당한 차이를 나타낸다(Crompton, 1997). 또한 해양무척추동물도 다양한 요인에 의해 중금속 축적에 영향을 받으며, 척추동물과 마찬가지 로 노출기간 및 노출농도에 의해 가장 큰 영향을 받는 다(Wen-Xiong Wang, 1999; Jacqueline et al., 2010). 연체 동물에 있어 소화선 및 아가미는 중금속의 체내 축적 및 해독과정에서 중요한 기능을 담당하는 장기로서(Marigómez et al., 2002), 특히 아가미는 중 금속의 체내축적과 관련하여 기본적인 기능을 담당 하는 조직으로 자연환경과 체내의 이온 흡수 및 배설 을 담당하게 된다(Lorenzo et al., 2005). Mussle, Mytilus galloprovincialis에서 $80 \mu \mathrm{g} / \mathrm{L}$ 구리이온의 독 성에 의한 실험결과 라이소좀의 조직학적 이상이 발 견되었으며(E.K. Raftopoulou and V.K. Dimitriadis, 2011), 이는 세포내 효소 작용의 이상을 야기하여 체내의 면역력을 저하시키는 결과를 보인다.

전복의 기관별 구리이온의 축적은 간췌장 내에서 는 2주 후의 $40 \mu \mathrm{g} / \mathrm{L}$ 농도, 아가미 내에서는 2주후부 터 $20 \mu \mathrm{g} / \mathrm{L}$ 이상의 농도에서 유의한 증가가 관찰되었 으나, 근육 내의 구리이온의 유의한 변화는 나타나지 않았다. 해양무척추동물에서 구리이온의 축적은 baltic clams, Macoma balthica에서 30 40 $\mu \mathrm{g} / \mathrm{L}$ 농도에서 13 일 후에 유의한 체내 축적이 나타났다(Ballan et al., 2001). 따라서 전복은 적어도 구리이온농도 40 $\mu \mathrm{g} / \mathrm{L}$ 에서 적어도 14 일 이후 간췌장 및 아가미 내에서 2주후부터 유의한 축적이 발생할 것으로 예상되며, 이와 같은 경향은 pearl oyster의 구리이온의 축적양 상과도 유사하다 $(\mathrm{Gu}$ jing et al., 2006).

구리이온와 같은 필수 미량 금속은 연체동물의 체 내에 흡수되어 정상적인 생명활동의 유지와 생리적 반응의 항상성 유지에 이용되기도 하지만, 필요 이상 의 농도에 노출될 경우 세포 내부의 구조적 이상을
유발하거나 생체 기능의 장애를 일으켜 생리적 활동 에 부정적인 영향을 끼치게 된다(Kawai, 1959; Sutherland et al., 1981). 구리이온는 어류의 성장에 영향을 미치며(Davis and Mertz, 1987; Lall, 2002), 성장 감소 및 스트레스를 유발하기도 한다(Niyogi et al., 2006; Gert Flik et al., 2002). 전복에서 보고된 각종 중금속에 의한 성장 저해는 카드뮴, 납, 망간 및 아연 등에서 공통적으로 일어난다(Takaomi arai et al., 2002). 어류 의 경우 아가미나 체표의 세포 손상과 점액의 과다생 성이 금속독성에 대한 방어기작으로 작용하여 산소 의 소비율을 저하시킴을 보고하였다(Kang et al., 2003). 성장과 연결된 산소소비율의 저하는 성장의 저하로 나타난다. 그 외에도 구리독성에 의한 간조직 의 핵응축, 세포질 혼탁 및 과립변성 등의 간 손상은 식욕부진의 일부 원인이 된다(De Boeck et al., 1997). 어류의 간과 유사한 기능을 전복의 간췌장에서도 이 러한 변화가 나타날 것으로 사료된다. 본 실험에서도 전복의 성장률 지표인 WER은 $40 \mu \mathrm{g} / \mathrm{L}$ 의 구리이온농 도에서 4주후에 유의한 감소가 나타났으며, 다른 지 표인 DISL은 2주후의 $\mathrm{Cu}$ 농도 $40 \mu \mathrm{g} / \mathrm{L}, 4$ 주후의 구리 이온농도 $20 \mu \mathrm{g} / \mathrm{L}$ 이상에서 유의하게 감소하였다. 이 같은 결과는 구리이온농도 $40 \mu \mathrm{g} / \mathrm{L}$ 이상에 노출된 전복은 적어도 2주후에 성장이 감소할 수 있다는 것 을 의미한다.

\section{참고문헌}

APHA-AWWA-WEF.: Standard methods for the examination of water and wastewater. 18th. Ed., APHA, Washington, D. C., 1992.

Ballan C., Dufrancais, A.Y. Jeantet, A. Geffard, J.C. Amiard and C. Amiard-Triquet: Cellular and tissular distribution of copper in an intrasedimentary bivalve, 
the Baltic clam Macoma balthica, originating from a clean or a metal-rich site, Can. J. Fish. Aquat. Sci. 58: 1964-1974, 2001.

Bryan, G. W.: Heavy metal contamination in the sea. In Marine Pollution, R. Johnston, eds., Academic Press, New York, 185-302, 1976.

Cropton T. R., Toxicants in the Aqueous Ecosystem, John \& Sons Ltd, 1997.

Davis, K.G., Mertz, W.: Copper. In: Mertz, W. (Ed.), Trace Elements in Human and Animals Nutrition. Academic Press, New York: 301-364, 1987.

De Boeck G, Vlaeminck and R Blust.: Effectsif sublethal coper exposure on copper accumulation, food consumption, growth, energy stores, and nucleic acid content in common carp. Arch. Environ. Contam. Toxicol. 33: 415-422, 1997.

E.K. Raftopoulou and V.K. Dimitriadis: Comparative study of the accumulation and detoxification of $\mathrm{Cu}$ (essential metal) and $\mathrm{Hg}$ (nonessential metal) in the digestive gland and gills of mussels Mytilus galloprovincialis, using analytical and histochemical techniques. Chemosphere Volume 83, Issue 8: 11551165, 2011.

Fernandes JC and Henriques FS.: Biochemical, physiological and structural effects of excess copper in plants, Botany Rev 57: 246-273, 1991.

Geret F. and M. J. Bebianno.: Does Zinc produce reactive oxygen species in Ruditapes decussatus. Ecotoxicol. Safe. 57: 399-409, 2004.

Gert Flik, Xander J. H. X. Stouthart, F. A. Tom Spanings, Robert A. C. Lock, James C. Fenwick, Sjoerd E. Wendelaar Bonga: Stress response to waterborne $\mathrm{Cu}$ during early life stages of carp, Cyprinus carpio
Aquatic Toxicology, Volume 56, Issue 3: 167-176, 2002.

Gu Jing, Yu Li, Liping Xie, Rongqing Zhang: Metal accumulation and enzyme activities in gills and digestive gland of pearl oyster (Pinctada fucata) exposed to copper. Comparative Biochemistry and Physiology Part C: Toxicology \& Pharmacology, Volume 144, Issue 2: 184-190, 2006

Jacqueline A. Leea, Islay D. Marsdena and Chris N. Glover: The influence of salinity on copper accumulation and its toxic effects in estuarine animals with differing osmoregulatory strategies. Aquatic Toxicology, Available online 13 April, 2010.

Kawai K.: The cytochrome system in marine lamellibranch tissues. Biol Bull 117:125-132, 1959.

Lall, S.P.: The minerals. In: Halver, J.E., Hardy, R.W.(Eds.), Fish Nutrition. Academic Press, New York: 259308, 2002.

Lidon FC and Henriques FS.: Limiting step on photo-synthesis of rice plants treated with varying copper levels, J Plant Physiology 138: 115-118, 1991.

Lidon FC, Ramalho J and Henriques FS.: Copper inhibition of rice photosynthesis, J. Plant Physiology 142: 1217, 1993.

Lorenzo J.I., R. Beiras, V.K. Mubiana and R. Blust : Copper uptake by Mytilus edulis in the presence of humic acids. Environ. Toxicol. Chem., 24-4, 973-980, 2005. Marigómez, M. Soto, M.P. Cajaraville, E. Angulo and L. Giamberini, Cellular and subcellular distribution of metals in molluscs. Microsc. Res. Tech., 56, 358$392,2002$.

Marr, J.C.A., J. Lipton, D. Cacela, J.A. Hansen, H.L. Bergman, J.S. Meyer and C. Hogstrand: Realtion- 
ships between copper exposure duration, tissue copper concentration, and rainbow trout growth. Aquat. Toxicol., 36: 17-30, 1996.

M. Minghettia, M.J. Leavera, E. Carpeneb and S.G. Georgea: Copper transporter 1, metallothionein and glutathione reductase genes are differentially expressed in tissues of sea bream (Sparus aurata) after exposure to dietary or waterborne copper. Toxicology \& Pharmacology Volume 147, Issue 4: 450-459, 2008.

Mcgeer, J.C., C. Szebedinszky, D.G. Mcdonald, and C.M. Wood: Effects of chronic sublethal exposure to waterborne $\mathrm{Cu}, \mathrm{Cd}$ or $\mathrm{Zn}$ in rainbow trout. 1: Iono-regulatory disturbance and metabolic costs. Aquat. Toxicol. 50:231-243, 2000.

Niyogi S., C.N. Kamunde, C.M. Wood: Food selection, growth and physiology in relation to dietary sodium chloride content in rainbow trout (Oncorhynchus mykiss) under chronic waterborne $\mathrm{Cu}$ exposure Aquatic Toxicology, Volume 77, Issue 2: 210-221, 2006.

Ouzounidou G: Copper-induced changes on growth, metal content and photosynthetic functions of Alyssum montanum L. plants. Environmental and Experimental Botany 34: 165-172, 1994.

Pagenkopf, G.K.: Gill surface interaction model for tracemetal toxicity to fishes: role of complexation, $\mathrm{pH}$ and water hardness. Environ. Sci. Technol., 17: 342-347, 1983.

Perschbacher PW and Wurts WA.: Effects of calcium and magnesium hardness on acute copper toxicity to juvenile channel catfish, Ictalurus punctatus. Aquacul- ture: $172: 275-280,1999$.

Sherba, M., D.W. Dunham and H.H. Harvey: Sublethal copper toxicity and food response in the freshwater crayfish, Cambarus bartonii (Cambaridae, Decapoda, Crustacea). Ecotoxicol. Environ. Saf., 46: 329-333, 2000.

Sutherland J, Major CW.: Internal heavy metal changes as a consequence of exposure of Mytilus edulis, the blue mussel, to elevated external copper (II) levels. Comp Biochem Physiol 68C: 63-67, 1981.

Takaomi Arai, Masaru Maeda, Hiroshi yamakawa Akiyoshi kamatani and Nobuyuki Miyazaki: Growth effect on the uptake and elimination of trace metals in the abalones Haliotis. Fisheries science 68: 1094-1098, 2002.

Wen-Xiong Wang, Nicholas S. Fisher: Delineating metal accumulation pathways for marine invertebrates The Science of The Total Environment, Volumes 237: 459-472, 1999.

Wong, P.P.K., L.M. Chu and C.K. Wong: Study of toxicity and bioaccumulation of copper in the silver sea bream Sparus sarba. Environ. Int., 25: 417-422, 1999.

Zar J.H.: Biostatistical Analysis. Prentice Hall, London, 662, 1996.

강주찬, 김재원, 김성길, 황운기: 구리 노출에 따른 넙치, Paralichthys olivaceus 치어의 만성독성. 한국환 경생물학회지, 21-1: 36-41, 2003.

Manuscript Received : August 24, 2011

Revised : August 01, 2012 Accepted: August 02, 2012 